Published in final edited form as:

Semin Nephrol. 2013 July ; 33(4): 392-399. doi:10.1016/j.semnephrol.2013.05.011.

\title{
Epigenomics of Hypertension
}

\author{
Mingyu Liang ${ }^{*}$, Allen W. Cowley Jr. ${ }^{*}$, David L. Mattson ${ }^{*}$, Theodore A. Kotchen ${ }^{\#}$, and Yong \\ Liu \\ *Department of Physiology, Medical College of Wisconsin, Milwaukee, WI \\ \#Department of Medicine, Medical College of Wisconsin, Milwaukee, WI
}

\section{Abstract}

Multiple genes and pathways are involved in the pathogenesis of hypertension. Epigenomic studies of hypertension are beginning to emerge and hold great promise of providing novel insights into the mechanisms underlying hypertension. Epigenetic marks or mediators including DNA methylation, histone modifications, and non-coding RNA can be studied at a genome or near-genome scale using epigenomic approaches. At the single gene level, several studies have identified changes in epigenetic modifications in genes expressed in the kidney that correlate with the development of hypertension. Systematic analysis and integration of epigenetic marks at the genome scale, demonstration of cellular and physiological roles of specific epigenetic modifications, and investigation of inheritance are among the major challenges and opportunities for future epigenomic and epigenetic studies of hypertension.

Essential hypertension is a multifactorial disease involving multiple genetic and environmental factors and mediated by alterations in multiple biological pathways. Because the non-genetic mechanisms may involve epigenetic modifications, epigenomics is one of the latest concepts and approaches brought to bear on hypertension research. In this article, we summarize briefly the concepts and techniques for epigenomics, discuss the rationale for applying epigenomic approaches to study hypertension, and review the current state of this research area.

\section{Concepts and techniques of epigenomics}

Epigenetics is the study of molecular changes (epigenetic marks or mediators) and associated phenotypes that are mitotically or meiotically inheritable but do not involve changes in DNA nucleotide sequence. Epigenetic marks or mediators contribute to biological regulation by influencing gene expression. Epigenomics is the study of epigenetic marks at a genome or near-genome scale. DNA methylation, histone modification, and noncoding RNA are three major types of epigenetic mediators, all of which can be studied at a genome or near-genome scale. Several examples of techniques for epigenomic analysis are listed in Table 1, and key features of these techniques are briefly discussed below. For a more detailed introduction of these techniques, refer to recent reviews published elsewhere. ${ }^{1,2,3,4}$

() 2013 Elsevier Inc. All rights reserved.

Correspondence: Mingyu Liang, Tel: 4149558539; Fax: 4149556546; mliang@ mcw.edu.

Publisher's Disclaimer: This is a PDF file of an unedited manuscript that has been accepted for publication. As a service to our customers we are providing this early version of the manuscript. The manuscript will undergo copyediting, typesetting, and review of the resulting proof before it is published in its final citable form. Please note that during the production process errors may be discovered which could affect the content, and all legal disclaimers that apply to the journal pertain.

Financial disclosure and conflict of interest statement: None. 
It is important to recognize that epigenomic analysis has very different requirements than genomic analysis even though epigenomic analysis often involves examination of DNA. With a few exceptions, genomic sequence is identical across all cells in an individual and remains the same throughout an individual's lifetime. The epigenomes, however, are different between cell types and may undergo dynamic changes in response to environmental cues. Many of the variables that one typically considers in a physiological or gene expression study but might not take into account in a genomic study, such as cell type, age, disease, treatment, and so on, should be considered in an epigenomic study.

One of the most widely studied epigenetic marks is 5-methylcytosine $(5 \mathrm{mC})$ found in cytosine-guanine dinucleotides $(\mathrm{CpG}){ }^{5,6}$ Of particular interest are $\mathrm{CpG}$ sites located in $\mathrm{CpG}$ islands which are clusters of $\mathrm{CpG}$ sites showing dynamic variations of methylation levels and often colocalized with cis regulatory elements such as gene promoters. Increased DNA methylation (hypermethylation) in $\mathrm{CpG}$ islands within or close to gene promoters is typically, although not always, associated with suppression of transcriptional activity. Genomic segments of interest can be enriched by affinity purification using antibodies or other proteins that recognize methylated DNA. Alternatively, genomic segments of interest, such as segments enriched for $\mathrm{CpG}$ islands, can be obtained by digestion using specific endonucleases. The genomic segments can then be identified or mapped to single-base resolution using microarray hybridization or next-generation sequencing. ${ }^{1,2,7}$ Other types of nucleotide modifications, notably 5-hydroxymethylcytosine $(5 \mathrm{hmC})$, may also be important for epigenetic regulation. $8,95 \mathrm{hmC}$ is one of the intermediates in the process of $5 \mathrm{mC}$ demethylation catalyzed by the ten-eleven translocation family of dioxygenases. $5 \mathrm{hmC}$ could play a role in gene regulation distinct from $5 \mathrm{mC}$. Methods for genome-wide analysis of $5 \mathrm{hmC}$ at single-base resolution have been reported recently. ${ }^{10,11}$

Post-translational modifications of histones, such as methylation and acetylation, are another major type of epigenetic marks. Proteomic techniques can be used to analyze a large number of histone modifications simultaneously. ${ }^{12}$ DNA segments that bind to a histone with a specific protein modification can be examined by cross-linking DNA with histones followed by immunoprecipitation using an antibody recognizing the histone with the specific modification. The isolated DNA segments can then be identified with microarray or sequencing. ${ }^{4}$ Histones may affect gene expression by altering chromatin structure. Several techniques are available for analyzing chromatin structure at a genome-scale. ${ }^{13}$

Regulatory, non-coding RNA may contribute importantly to epigenetic regulation. ${ }^{14,15}$ Noncoding RNA, particularly long non-coding RNA, may play a crucial role in conferring siteor gene-specificity to epigenetic modification. Non-coding RNA can be identified by RNAseq, sometimes with further support from identification of transcriptionally active genomic segments based on chromatin immunoprecipitation analysis. ${ }^{3,16,17,18}$ Some non-coding RNA molecules do not have a poly(A) tail and can only be identified with RNA-seq methods that do not use poly(A) selection.

Association between epigenetic marks, especially DNA methylation, and a phenotype can be investigated at the genome scale in epigenome-wide association studies (EWAS). ${ }^{19}$ Similar to genome-wide association studies (GWAS), EWAS often require a sample size of several hundred or more. ${ }^{19}$ The sample size of an EWAS is primarily determined by the magnitude of methylation rate differences among individuals, the impact of the methylation difference on the phenotype, and the number of methylation marks analyzed.

\section{Epigenomics of hypertension}

Hypertension affects $29 \%$ of the adult population in the US and costs 93.5 billion dollars in 2010. 20,21 Hypertension is a major risk factor for stroke, myocardial infarction, heart failure, 
and end-stage renal disease. About $50 \%$ of hypertensive patients in the US do not have their blood pressure adequately controlled, in many cases due to non-adherence and other disease management issues. ${ }^{20,22}$ Importantly, about 5 million patients in the US are apparently resistant to current anti-hypertensive treatments (hypertensive despite taking at least three antihypertensive medications). ${ }^{23}$ Patients with apparent treatment-resistant hypertension are more likely to be blacks and have obesity, chronic kidney disease, and Framingham 10-year coronary risk $>20 \% .^{23}$

Arterial blood pressure is the product of cardiac output and total peripheral vascular resistance. Several physiological and neurohormonal mechanisms regulate cardiac output and/or peripheral resistance and contribute to maintain the homeostasis of arterial blood pressure. These mechanisms involve several organ systems including the kidney and the cardiovascular, nervous, endocrine, and immune systems. The kidney plays a key role in this regulatory network. ${ }^{24,25,26}$ Genes that underlie Mendelian forms of human hypertension typically affect tubular transport in the kidney directly or indirectly. ${ }^{27}$ The molecular mechanisms underlying common forms of essential hypertension, however, remain poorly understood.

Although the multifactorial nature of hypertension is widely recognized, much of hypertension research has been focused on single genes or single regulatory pathways. The approach is useful despite its simplicity. Abnormalities in one gene or one pathway may very well make measurable contribution to the development of hypertension in a specific, defined setting (a specific animal model, a well-defined subset of patients). It would be valuable to identify these abnormalities. The approach also has a strong practical appeal since numerous methods are available for analyzing and experimentally manipulating one gene or one mechanism. It is often challenging to interpret network data and difficult (if possible at all) to experimentally manipulate a regulatory network. Nonetheless, understanding molecular regulatory networks on a genome-wide scale is undoubtedly what is needed to truly understand the disease mechanism of hypertension and its associated comorbidities.

Analysis of transcriptomes and proteomes is a powerful approach for studying molecular regulatory networks. ${ }^{28,29}$ Interestingly, transcriptome and proteome analysis has provided evidence for broad, genome-wide relevance of epigenetic regulatory mechanisms in hypertension. Analysis of transcriptomes and proteomes has been carried out in several organs or cell types relevant to blood pressure regulation in several models of hypertension. ${ }^{30,31}$ Enhanced sensitivity of blood pressure to salt intake is observed in a majority of hypertensive patients, especially in African Americans. ${ }^{32,33}$ The Dahl saltsensitive (SS) rat is a commonly used genetic model that recapitulates the increased blood pressure salt-sensitivity and exacerbated renal injury observed in African American hypertensive patients. ${ }^{34,35,36}$

Studies have been performed to analyze transcriptomes or proteomes in the renal cortex, renal medulla, or the medullary thick ascending limb of the Loop of Henle in SS, SS.13 ${ }^{\mathrm{BN}}$, SS. $13^{\mathrm{BN} 5}$, and/or SS. $13^{\mathrm{BN} 26}$ rats. ${ }^{37,38,39,40,41,42,43,44,45}$ The genomic sequences of the consomic SS. $13^{\mathrm{BN}}$ rat and congenic SS. $13^{\mathrm{BN} 5}$ and SS. $13^{\mathrm{BN} 26}$ rats are identical to SS except chromosome 13 (in SS.13 ${ }^{\mathrm{BN}}$ ) or segments of chromosome 13 (in SS.13 ${ }^{\mathrm{BN} 5}$ and SS.13 ${ }^{\mathrm{BN} 26}$ ) are replaced by the corresponding genomic segments derived from the Brown Norway (BN) rat. ${ }^{46,47}$ While genes differentially expressed between the consomic rat and the SS rat are enriched for genes located in the substituted chromosome, numerous genes located on other chromosomes are also differentially expressed. ${ }^{39,44}$ The magnitude of transcriptome difference between a consomic or congenic rat and the SS rat correlates with the magnitude of genetic difference to some extent but also with phenotypic differences. ${ }^{41}$ Moreover, 
replacement of different genomic segments can impact on a shared set of genes and pathways, while replacement of a small genomic segment can affect genes or pathways that are not affected by replacement of a larger genomic segment that encompasses the smaller segment. ${ }^{41}$

These data indicate extensive convergence and divergence of genomic effects that cannot be explained solely by the genomic sequence. It is likely that both genetic factors and nongenetic mechanisms contribute to the alterations of gene expression and eventually the development of salt-sensitive hypertension in these rats. Some of the non-genetic mechanisms may involve epigenetic modifications that occur as direct or indirect consequences of genomic sequence variations and their interactions with dietary and other environmental factors.

We have proposed a tree-like paradigm to serve as a framework for integrating multiple genes and pathways that underlie the development of common forms of hypertension such as salt-sensitive hypertension (Figure 1) ${ }^{48}$ Multiple causal genes would resemble numerous leaves on a tree. A causal gene may impact on one or more intermediate molecular pathways (the small branches of the tree), which converge gradually to form larger branches, or intermediate physiological pathways. The various pathways eventually converge at final common pathways, which in the case of hypertension could be impairment of renal pressure natriuresis and diuresis, and result in the development of salt-sensitive hypertension and renal injury. The regulatory network operates within specific genomic contexts and interacts with environmental factors such as dietary salt levels. A thorough understanding of these complex phenotypes requires that most of the genes and pathways involved are identified and the regulatory network constructed. Epigenetic mechanisms may have an important role in this tree-like paradigm (Figure 1), and it is highly likely that epigenetic marks relevant to hypertension are distributed widely throughout the genome, many of which probably have not been identified. Application of epigenomic approaches, therefore, holds great promise of revealing novel mechanisms underlying the development of hypertension.

Epigenomic studies of hypertension are just beginning to emerge, even though the concept has been proposed earlier. ${ }^{49}$ Wang and colleagues conducted a genome-wide methylation analysis in leukocytes obtained from 8 hypertensive cases and 8 normotensive age-matched controls. ${ }^{50}$ The methylation analysis was performed using the HumanMethylation27

BeadChip from Illumina. None of the $\mathrm{CpG}$ sites examined reached statistical significance following multiple testing corrections, with the most significant $\mathrm{CpG}$ site showing a false discovery rate of 0.75 . This is not surprising given the small number of subjects with varying genetic background and possible phenotypic variations, complex cellular composition of the leukocyte samples, and the large number of $\mathrm{CpG}$ sites tested. Nevertheless, some of the most significantly different $\mathrm{CpG}$ sites (according to $\mathrm{p}$ values without multiple testing correction), including a CpG site in the sulfatase 1 gene (SULF1), were experimentally validated by sequencing in additional cohorts of hypertensive and control subjects.

An epigenomic study was performed in our laboratory to examine the influence of diet on the development of hypertension in the SS rat. As we previously described, the progression of salt-sensitive hypertension and renal disease is dramatically altered in SS rats fed diets containing different sources of protein. ${ }^{51,52}$ In the recent study, we confirmed our earlier observations that indicated that SS rats obtained from a breeding colony maintained on an AIN-76A diet (a purified rodent diet containing casein as its protein source) develop more severe salt-sensitive hypertension and renal disease when compared to age-matched Dahl SS rats obtained from a colony fed a grain-based diet (LabDiet 5L79). A genome-wide methylation analysis using the reduced representation bisulfite sequencing method ${ }^{17}$ and an 
RNA-seq analysis subsequently demonstrated multiple genes associated with inflammation, cell growth, and cell matrix formation or degradation with reciprocal DNA methylation and mRNA expression patterns in the renal outer medulla. These exciting data indicate that DNA methylation may be a mechanism leading to the protective effect of different diets on the development of disease phenotypes; as a corollary, epigenomic studies have the potential to generate unique insight into disease mechanisms.

\section{Epigenetic regulation of kidney genes relevant to hypertension}

While epigenome-wide studies of hypertension are just beginning to emerge, a number of studies have reported changes in epigenetic modification (presumably mitotically inheritable) of specific genes associated with development of hypertension. Changes in DNA methylation and histone modification have been shown to correlate with the expression of several genes involved in the development of hypertension or hypertensive tissue injury as discussed below. Non-coding RNA, especially microRNAs, may also influence the development of hypertension and hypertensive tissue injury, ${ }^{53,54}$ although it remains to be determined whether mitotically heritable changes are induced by non-coding RNA in hypertension. Some of the epigenetic modifications associated with hypertension have been reviewed elsewhere. ${ }^{55,56}$ We will highlight several examples here with a focus on genes particularly relevant to the role of the kidney in blood pressure regulation or the development of hypertension. Most of these examples are summarized in Figure 2.

Environmental stress in early life or during critical periods of fetal development, the latter of which often leads to low birth weight, is correlated with the development of hypertension (and several other conditions) in adult life. ${ }^{57}$ Epigenetic modifications are commonly cited as a possible mechanism for this phenomenon of developmental programming. Although specific epigenetic modifications associated with developmental programming of adult hypertension remains largely unidentified, several cases related to genes expressed in the kidney have been reported. For example, uteroplacental insufficiency was found to specifically decrease $\mathrm{CpG}$ methylation of the BstU I digestion site in the promoter of p53 gene in the kidneys of a rat model of intrauterine growth retardation. ${ }^{58}$ The hypomethylation of renal p53 promoter was associated with up-regulation of p53 mRNA and increased apoptosis in the kidney. ${ }^{58}$ Fetal exposure to excess glucocorticoids leads to the development of hypertension in adult offspring. It was reported that maternal treatment with dexamethasone increased renal expression of glucocorticoid receptor in 6-month-old offspring by several fold. ${ }^{59}$ Methylation-sensitive PCR analysis indicated that this upregulation of renal glucocorticoid receptor was associated with hypomethylation of the glucocorticoid receptor promoter. ${ }^{59}$

Activated glucocorticoid receptors can bind to negative glucocorticoid-responsive elements in the promoter regions and suppress target gene expression. ${ }^{60}$ One of the target genes of glucocorticoid receptors appears to be WNK4, a regulator of sodium reabsorption in the kidney. ${ }^{61}$ It was reported that stimulation $\beta 2$-adrenergic receptor resulted in cyclic AMPdependent inhibition of histone deacetylase- 8 activity in the kidney, increased histone acetylation, increased accessibility and binding of glucocorticoid receptors to a negative glucocorticoid-responsive element in WNK4 promoter, and decreased transcription of WNK4. This pathway may contribute to increased sodium reabsorption in the kidney and the development of salt-sensitive hypertension in mouse and rat models. ${ }^{61}$

Glucocorticoids (primarily cortisol in human and corticosterone in rodents) can bind to mineralocorticoid receptors with equal affinity as mineralocorticoids (primarily aldosterone). The binding would stimulate sodium reabsorption in the distal nephron and, when excessive, could lead to the development of hypertension. The high expression level of 
11ß-hydroxysteroid dehydrogenase type 2 in the distal nephron, which converts active glucocorticoids to inactive glucocorticoids, is crucial for preventing abnormal stimulation of mineralocorticoid receptors by glucocorticoids. The tissue-specific enrichment pattern of $11 \beta$-hydroxysteroid dehydrogenase type 2 is inversely correlated with the degree of methylation of its promoter. ${ }^{62}$ It suggests that promoter methylation could contribute to the role of renal 11ß-hydroxysteroid dehydrogenase type 2 in the regulation of volume and blood pressure homeostasis. Indeed, it was reported that renal 11ß-hydroxysteroid dehydrogenase type 2 was down-regulated from birth through postnatal day 21 in an intrauterine growth retardation rat model of hypertension. The down-regulation was correlated with altered DNA methylation at birth in a gender-specific manner and decreased trimethylation of H3K36 in exon 5 at birth and at postnatal day 21 in both genders. ${ }^{63}$ Renal expression of the type 1 isoform of $11 \beta$-hydroxysteroid dehydrogenase, which converts inactive glucocorticoids back to active glucocorticoids, has also been shown to contribute to the development of salt-sensitive hypertension. ${ }^{48}$

Stimulation of mineralocorticoid receptors leads to increased sodium reabsorption in the distal nephron in part by up-regulating the expression of epithelial sodium channels (ENaC). Kone and colleagues reported that the transcriptional activity of ENaCa was regulated by histone H3 Lys-79 methyltransferase disruptor of telomeric silencing-1a (Dot1a) and the sequence-specific DNA binding protein ALL1 fused gene from chromosome 9 (Af9). ${ }^{64}$ They proposed that, in the absence of aldosterone, Dot1a would form a complex with Af9 and bind to $\mathrm{ENaCa} 5$-flanking region, which presumably facilitates methylation of Lys79 of histone $\mathrm{H} 3$ and suppresses $\mathrm{ENaCa}$ transcription. Aldosterone could disrupt this repressor complex by down-regulating or phosphorylating Dot1a and/or Af9, leading to up-regulation of $\mathrm{ENaCa}$.

Activation of systemic and/or local renin-angiotensin systems leads to the development of hypertension. Angiotensin converting enzyme 1 was up-regulated in several organs including the kidney in spontaneous hypertensive rats compared to Wistar-Kyoto rats. ${ }^{65}$ This up-regulation was associated with increased binding of histone 3 acetylation (H3Ac) and fourth lysine trimethylation (H3K4me3) but decreased binding of histone ninth lysine dimethylation (H3K9me2) to the promoter of the angiotensin converting enzyme 1 gene in the kidney and several other organs. ${ }^{65}$ Changes in promoter methylation have also been reported to correlate with changes in the expression of genes in the renin-angiotensin system in non-kidney organs. ${ }^{66}$ For example, maternal exposure to low protein diet, which leads to hypertension in adult offspring, was reported to cause up-regulation of angiotensin type 1 receptor and hypomethylation of its promoter in the adrenal gland. ${ }^{67}$

A major challenge in epigenetic research is demonstrating a causal contribution of specific epigenetic marks to the determination of a phenotype. The enzymes that catalyze DNA methylation, demethylation, or histone modifications do not in themselves confer any sitespecificity. Targeting these enzymes will affect many epigenetic marks in a largely nonspecific manner. Several methods have been developed to enable targeted changes in DNA methylation at specific genomic sites. ${ }^{68,69,70}$ The methods typically involve fusing a DNA methylation enzyme with a DNA binding protein engineered to recognize a specific genomic site. The DNA binding protein guides the methylation enzyme and introduces changes in methylation at the specific genomic site. Further improvement of these methods, especially their in vivo application, will be highly valuable to epigenetic research including epigenetic studies of hypertension. 


\section{Hypertension and epigenetic inheritance}

Essential hypertension has a significant level of heritability estimated to be up to $50 \%$ based on studies of twins. GWAS have identified numerous DNA polymorphisms that can account for parts of many quantitative traits. Hypertension, however, is one of the most notable examples in which the DNA polymorphisms identified by GWAS account for only a small fraction of the trait. ${ }^{71}$ The missing heritability may be due to several reasons, one of which being epigenetic inheritance. ${ }^{71}$

Whether and how epigenetic marks and any associated phenotypes are inherited transgenerationally in mammalian species remains an intensively investigated question. DNA methylation is erased following fertilization and then again during the formation of primordial germ cells. ${ }^{72}$ Some evidence suggests that the erasure is not complete, leaving behind methylation marks that might help to maintain aspects of the epigenetic pattern through generations. ${ }^{73,74,75}$ Trans regulatory factors in zygotes, such as RNA, might also help to transmit epigenetic patterns through generations. ${ }^{76,77}$

Because of the possibility of incomplete erasure of epigenetic patterns during reprogramming, epigenetic marks and associated phenotypes have to be transmitted from the F0 generation (the exposed generation) to F3 to be considered transgenerationally inheritable and not the consequence of initial environmental exposure. The primordial germ cell that gives rise to an F2 individual was formed when F1 developed as an embryo in the uterus of F0 and could have been exposed to any environmental cue that the F0 individual was exposed to (Figure 3). Transmission from F0 to F2 would be sufficient evidence for transgenerational inheritance if the environmental exposure of $\mathrm{F} 0$ took place prior to pregnancy (Figure 3). Developmental programming that involves only one or two generations, as discussed earlier in the article, could still be direct results of initial environmental exposure and does not require or prove transgenerational inheritance. Clear evidence for transgenerational inheritance of epigenetic marks and associated phenotypes remains scarce in all areas of research and absent in hypertension research.

\section{Acknowledgments}

Financial support: This work was supported by National Institutes of Health grants HL082798, HL111580, and HL029587.

\section{References}

1. Bock C, Tomazou EM, Brinkman AB, Müller F, Simmer F, Gu H, Jäger N, Gnirke A, Stunnenberg HG, Meissner A. Quantitative comparison of genome-wide DNA methylation mapping technologies. Nat Biotechnol. 2010; 28(10):1106-14. [PubMed: 20852634]

2. Laird PW. Principles and challenges of genomewide DNA methylation analysis. Nat Rev Genet. 2010; 11(3):191-203. [PubMed: 20125086]

3. Ozsolak F, Milos PM. RNA sequencing: advances, challenges and opportunities. Nat Rev Genet. 2011; 12(2):87-98. [PubMed: 21191423]

4. Park PJ. ChIP-seq: advantages and challenges of a maturing technology. Nat Rev Genet. 2009; 10(10):669-80. [PubMed: 19736561]

5. Bird A. DNA methylation patterns and epigenetic memory. Genes Dev. 2002; 16(1):6-21. [PubMed: 11782440]

6. Deaton AM, Bird A. CpG islands and the regulation of transcription. Genes Dev. 2011; 25(10): 1010-22. [PubMed: 21576262]

7. Gu H, Smith ZD, Bock C, Boyle P, Gnirke A, Meissner A. Preparation of reduced representation bisulfite sequencing libraries for genome-scale DNA methylation profiling. Nat Protoc. 2011; 6(4): 468-81. [PubMed: 21412275] 
8. Branco MR, Ficz G, Reik W. Uncovering the role of 5-hydroxymethylcytosine in the epigenome. Nat Rev Genet. 2011; 13(1):7-13. [PubMed: 22083101]

9. Song CX, Yi C, He C. Mapping recently identified nucleotide variants in the genome and transcriptome. Nat Biotechnol. 2012; 30(11):1107-16. [PubMed: 23138310]

10. Booth MJ, et al. Quantitative sequencing of 5-methylcytosine and 5-hydroxymethylcytosine at single-base resolution. Science. 2012; 336:934-937. [PubMed: 22539555]

11. $\mathrm{Yu} \mathrm{M}$, et al. Base-resolution analysis of 5-hydroxymethylcytosine in the mammalian genome. Cell. 2012; 149:1368-1380. [PubMed: 22608086]

12. Tian Z, Tolić N, Zhao R, Moore RJ, Hengel SM, Robinson EW, Stenoien DL, Wu S, Smith RD, Paša-Tolić L. Enhanced top-down characterization of histone post-translational modifications. Genome Biol. 2012; 13(10):R86. [PubMed: 23034525]

13. Zentner GE, Henikoff S. Surveying the epigenomic landscape, one base at a time. Genome Biol. 2012; 13(10):250. [PubMed: 23088423]

14. Mercer TR, Dinger ME, Mattick JS. Long non-coding RNAs: insights into functions. Nat Rev Genet. 2009; 10(3):155-9. [PubMed: 19188922]

15. Zaratiegui M, Martienssen RA. SnapShot: small RNA-mediated epigenetic modifications. Cell. 2012; 151(2):456-456. e1. [PubMed: 23063132]

16. Guttman M, Amit I, Garber M, French C, Lin MF, Feldser D, Huarte M, Zuk O, Carey BW, Cassady JP, Cabili MN, Jaenisch R, Mikkelsen TS, Jacks T, Hacohen N, Bernstein BE, Kellis M, Regev A, Rinn JL, Lander ES. Chromatin signature reveals over a thousand highly conserved large non-coding RNAs in mammals. Nature. 2009; 458(7235):223-7. [PubMed: 19182780]

17. Landgraf P, Rusu M, Sheridan R, Sewer A, Iovino N, Aravin A, Pfeffer S, Rice A, Kamphorst AO, Landthaler M, Lin C, Socci ND, Hermida L, Fulci V, Chiaretti S, Foà R, Schliwka J, Fuchs U, Novosel A, Müller RU, Schermer B, Bissels U, Inman J, Phan Q, Chien M, Weir DB, Choksi R, De Vita G, Frezzetti D, Trompeter HI, Hornung V, Teng G, Hartmann G, Palkovits M, Di Lauro R, Wernet P, Macino G, Rogler CE, Nagle JW, Ju J, Papavasiliou FN, Benzing T, Lichter P, Tam W, Brownstein MJ, Bosio A, Borkhardt A, Russo JJ, Sander C, Zavolan M, Tuschl T. A mammalian microRNA expression atlas based on small RNA library sequencing. Cell. 2007; 129(7):1401-14. [PubMed: 17604727]

18. Pauli A, Valen E, Lin MF, Garber M, Vastenhouw NL, Levin JZ, Fan L, Sandelin A, Rinn JL, Regev A, Schier AF. Systematic identification of long noncoding RNAs expressed during zebrafish embryogenesis. Genome Res. 2012; 22(3):577-91. [PubMed: 22110045]

19. Rakyan VK, Down TA, Balding DJ, Beck S. Epigenome-wide association studies for common human diseases. Nat Rev Genet. 2011; 12(8):529-41. [PubMed: 21747404]

20. Egan BM, Zhao Y, Axon RN. US trends in prevalence, awareness, treatment, and control of hypertension, 1988-2008. JAMA. 2010; 303:2043-2050. [PubMed: 20501926]

21. Heidenreich PA, Trogdon JG, Khavjou OA, Butler J, Dracup K, Ezekowitz MD, Finkelstein EA, Hong Y, Johnston SC, Khera A, Lloyd-Jones DM, Nelson SA, Nichol G, Orenstein D, Wilson PW, Woo YJ, et al. Forecasting the future of cardiovascular disease in the United States: a policy statement from the American Heart Association. Circulation. 2011; 123:933-944. [PubMed: 21262990]

22. Kotchen TA. The search for strategies to control hypertension. Circulation. 2010; 122(12):1141-3. [PubMed: 20823382]

23. Egan BM, Zhao Y, Axon RN, Brzezinski WA, Ferdinand KC. Uncontrolled and apparent treatment resistant hypertension in the United States, 1988 to 2008. Circulation. 2011; 124(9):1046-58. [PubMed: 21824920]

24. Cowley AW Jr. Long-term control of arterial blood pressure. Physiol Rev. 1992; 72(1):231-300. [PubMed: 1731371]

25. Cowley AW Jr, Roman RJ. The role of the kidney in hypertension. JAMA. 1996; 275(20):1581-9. [PubMed: 8622250]

26. Guyton AC. Blood pressure control—special role of the kidneys and body fluids. Science. 1991; 252(5014):1813-6. [PubMed: 2063193]

27. Lifton RP, Gharavi AG, Geller DS. Molecular mechanisms of human hypertension. Cell. 2001; 104(4):545-56. [PubMed: 11239411] 
28. Liang M, Cowley AW, Greene AS. High throughput gene expression profiling: a molecular approach to integrative physiology. J Physiol. 2004; 554(Pt 1):22-30. [PubMed: 14678487]

29. Liang M, Cowley AW Jr, Hessner MJ, Lazar J, Basile DP, Pietrusz JL. Transcriptome analysis and kidney research: toward systems biology. Kidney Int. 2005; 67(6):2114-22. [PubMed: 15882254]

30. Malek RL, Wang HY, Kwitek AE, Greene AS, Bhagabati N, Borchardt G, Cahill L, Currier T, Frank B, Fu X, Hasinoff M, Howe E, Letwin N, Luu TV, Saeed A, et al. Physiogenomic resources for rat models of heart, lung and blood disorders. Nat Genet. 2006; 38:234-239. [PubMed: 16415889]

31. Marques FZ, Campain AE, Yang YH, Morris BJ. Meta-analysis of genome-wide gene expression differences in onset and maintenance phases of genetic hypertension. Hypertension. 2010; 56:319324. [PubMed: 20585107]

32. Sullivan JM, Prewitt RL, Ratts TE. Sodium sensitivity in normotensive and borderline hypertensive humans. Am J Med Sci. 1988; 295(4):370-7. [PubMed: 3284356]

33. Weinberger MH. Salt sensitivity of blood pressure in humans. Hypertension. 1996; 27(3 Pt 2):48190. [PubMed: 8613190]

34. Cowley AW Jr. The genetic dissection of essential hypertension. Nat Rev Genet. 2006; 7(11):82940. [PubMed: 17033627]

35. Rapp JP. Dahl salt-susceptible and salt-resistant rats. Hypertension. 1982; 4(6):753-63. [PubMed: 6754600]

36. Tobian L. Salt and hypertension. Lessons from animal models that relate to human hypertension. Hypertension. 1991; 17(1 Suppl):I52-8. [PubMed: 1987012]

37. Liang M, Yuan B, Rute E, Greene AS, Zou A-P, Soares P, McQuestion G, Slocum GR, Jacob HJ, Cowley AW Jr. Renal medullary genes in salt-sensitive hypertension: a chromosomal substitution and cDNA microarray study. Physiol Genomics. 2002; 8(2):139-149. [PubMed: 11875192]

38. Liang M, Yuan B, Rute E, Greene AS, Olivier M, Cowley AW Jr. Insights into Dahl salt-sensitive hypertension revealed by temporal patterns of renal medullary gene expression. Physiol Genomics. 2003; 12:229-237. [PubMed: 12488510]

39. Liang M, Lee NH, Wang H, Greene AS, Kwitek AE, Kaldunski ML, Luu TV, Frank BC, Bugenhagen S, Jacob HJ, Cowley AW Jr. Molecular Networks in Dahl Salt-Sensitive Hypertension Based on Transcriptiome Analysis of a Panel of Consomic Rats. Physiol Genomics. 2008; 34(1):54-64. [PubMed: 18430809]

40. Liu Y, Taylor NE, Lu L, Usa K, Cowley AW Jr, Ferreri NR, Yeo NC, Liang M. Renal medullary microRNAs in Dahl salt-sensitive rats: miR-29b regulates several collagens and related genes. Hypertension. 2010; 55(4):974-82. [PubMed: 20194304]

41. Lu L, Li P, Yang C, Kurth T, Misale M, Skelton MM, Moreno C, Roman RJ, Greene AS, Jacob HJ, Lazar J, Liang M, Cowley AW Jr. Dynamic convergence and divergence of renal genomic and biological pathways in protection from Dahl salt-sensitive hypertension. Physiol Genomics. 2010; 41(1):63-70. [PubMed: 20009007]

42. Mori T, Polichnowski A, Glocka P, Kaldunski M, Ohsaki Y, Liang M, Cowley AW Jr. High Perfusion Pressure Accelerates Renal Injury in Salt-Sensitive Hypertension. J Am Soc Nephrol. 2008; 19(8):1472-82. [PubMed: 18417720]

43. Tian Z, Greene AS, Usa K, Matus IR, Bauwens J, Pietrusz JL, Cowley AW Jr, Liang M. Renal regional proteomes in young Dahl salt-sensitive rats. Hypertension. 2008; 51:899-904. [PubMed: 18316652]

44. Yang C, Stingo FC, Ahn KW, Liu P, Vannucci M, Laud PW, Skelton M, O'Connor P, Kurth T, Ryan RP, Moreno C, Tsaih SW, Patone G, Hummel O, Jacob HJ, Liang M, Cowley AW Jr. Increased Proliferative Cells in the Medullary Thick Ascending Limb of the Loop of Henle in the Dahl Salt-Sensitive Rat. Hypertension. 2013; 61(1):208-15. [PubMed: 23184381]

45. Zheleznova NN, Yang C, Ryan RP, Halligan BD, Liang M, Greene AS, Cowley AW Jr. Mitochondrial proteomic analysis reveals deficiencies in oxygen utilization in medullary thick ascending limb of Henle in the Dahl salt-sensitive rat. Physiol Genomics. 2012; 44(17):829-42. [PubMed: 22805345]

46. Cowley AW Jr, Liang M, Roman RJ, Greene AS, Jacob HJ. Consomic rat model systems for physiological genomics. Acta Physiol Scand. 2004; 181(4):585-592. [PubMed: 15283774] 
47. Moreno C, Kaldunski ML, Wang T, Roman RJ, Greene AS, Lazar J, Jacob HJ, Cowley AW Jr. Multiple blood pressure loci on rat chromosome 13 attenuate development of hypertension in the Dahl S hypertensive rat. Physiol Genomics. 2007; 31(2):228-35. [PubMed: 17566075]

48. Liu Y, Singh RJ, Usa K, Netzel BC, Liang M. Renal Medullary 11 $\beta$-Hydroxysteroid Dehydrogenase Type 1 in Dahl salt-sensitive hypertension. Physiol Genomics. 2008; 36:52-58. [PubMed: 18826995]

49. Fornage M, Doris PA. Genomics and epigenomics of hypertension. Curr Opin Mol Ther. 2006; 8(3):206-14. [PubMed: 16774040]

50. Wang X, Falkner B, Zhu H, Shi H, Su S, Xu X, Sharma AK, Dong Y, Treiber F, Gutin B, Harshfield G, Snieder H. A genome-wide methylation study on essential hypertension in young african american males. PLoS One. 2013; 8(1):e53938. [PubMed: 23325143]

51. Mattson DL, Kunert MP, Kaldunski ML, Greene AS, Roman RJ, Jacob HJ, Cowley AW Jr. Influence of diet and genetics on hypertension and renal disease in Dahl salt-sensitive rats. Physiol Genomics. 2004; 16(2):194-203. [PubMed: 14600213]

52. Mattson DL, Meister CJ, Marcelle ML. Dietary protein source determines the degree of hypertension and renal disease in the Dahl salt-sensitive rat. Hypertension. 2005; 45(4):736-41. [PubMed: 15699463]

53. Kriegel AJ, Mladinov D, Liang M. Translational Study of MicroRNAs and its Application in Kidney Disease and Hypertension Research. Clin Sci (Lond). 2012; 122(10):439-47. [PubMed: 22283365]

54. Liang M, Liu Y, Mladinov D, Cowley AW Jr, Trivedi H, Fang Y, Xu X, Ding X, Tian Z. MicroRNA: A New Frontier in Kidney and Blood Pressure Research (invited review). Am J Physiol Renal Physiol. 2009; 297(3):F553-8. [PubMed: 19339633]

55. Frey FJ. Methylation of $\mathrm{CpG}$ islands: potential relevance for hypertension and kidney diseases. Nephrol Dial Transplant. 2005; 20(5):868-9. [PubMed: 15728268]

56. Millis RM. Epigenetics and hypertension. Curr Hypertens Rep. 2011; 13(1):21-8. [PubMed: 21125351]

57. Zandi-Nejad K, Luyckx VA, Brenner BM. Adult hypertension and kidney disease: the role of fetal programming. Hypertension. 2006; 47(3):502-8. [PubMed: 16415374]

58. Pham TD, MacLennan NK, Chiu CT, Laksana GS, Hsu JL, Lane RH. Uteroplacental insufficiency increases apoptosis and alters p53 gene methylation in the full-term IUGR rat kidney. Am J Physiol Regul Integr Comp Physiol. 2003; 285:R962-R970. [PubMed: 12869365]

59. Wyrwoll CS, Mark PJ, Waddell BJ. Developmental programming of renal glucocorticoid sensitivity and the renin-angiotensin system. Hypertension. 2007; 50(3):579-84. [PubMed: 17664394]

60. Liu Y, Mladinov D, Pietrusz JL, Usa K, Liang M. Glucocorticoid Response Elements and 11 $\beta$ Hydroxysteroid Dehydrogenases in the Regulation of Endothelial Nitric Oxide Synthase Expression. Cardiovasc Res. 2009; 81(1):140-7. [PubMed: 18716005]

61. Mu S, Shimosawa T, Ogura S, Wang H, Uetake Y, Kawakami-Mori F, Marumo T, Yatomi Y, Geller DS, Tanaka H, Fujita T. Epigenetic modulation of the renal $\beta$-adrenergic-WNK4 pathway in salt-sensitive hypertension. Nat Med. 2011; 17(5):573-80. [PubMed: 21499270]

62. Alikhani-Koopaei R, Fouladkou F, Frey FJ, Frey BM. Epigenetic regulation of 11 betahydroxysteroid dehydrogenase type 2 expression. J Clin Invest. 2004; 114(8):1146-57. [PubMed: 15489962]

63. Baserga M, Kaur R, Hale MA, Bares A, Yu X, Callaway CW, McKnight RA, Lane RH. Fetal growth restriction alters transcription factor binding and epigenetic mechanisms of renal 11betahydroxysteroid dehydrogenase type 2 in a sex-specific manner. Am J Physiol Regul Integr Comp Physiol. 2010; 299(1):R334-42. [PubMed: 20427719]

64. Zhang D, Yu ZY, Cruz P, Kong Q, Li S, Kone BC. Epigenetics and the control of epithelial sodium channel expression in collecting duct. Kidney Int. 2009; 75(3):260-7. [PubMed: 18818687]

65. Lee HA, Cho HM, Lee DY, Kim KC, Han HS, Kim IK. Tissue-specific upregulation of angiotensin-converting enzyme 1 in spontaneously hypertensive rats through histone code modifications. Hypertension. 2012; 59(3):621-6. [PubMed: 22311897] 
66. Rivière G, Lienhard D, Andrieu T, Vieau D, Frey BM, Frey FJ. Epigenetic regulation of somatic angiotensin-converting enzyme by DNA methylation and histone acetylation. Epigenetics. 2011; 6(4):478-89. [PubMed: 21364323]

67. Bogdarina I, Welham S, King PJ, Burns SP, Clark AJ. Epigenetic modification of the reninangiotensin system in the fetal programming of hypertension. Circ Res. 2007; 100:520-526. [PubMed: 17255528]

68. Li F, Papworth M, Minczuk M, Rohde C, Zhang Y, Ragozin S, Jeltsch A. Chimeric DNA methyltransferases target DNA methylation to specific DNA sequences and repress expression of target genes. Nucleic Acids Res. 2007; 35(1):100-12. [PubMed: 17151075]

69. Nomura W, Barbas CF 3rd. In vivo site-specific DNA methylation with a designed sequenceenabled DNA methylase. J Am Chem Soc. 2007; 129(28):8676-7. [PubMed: 17583340]

70. Xu GL, Bestor TH. Cytosine methylation targetted to pre-determined sequences. Nat Genet. 1997; 17(4):376-8. [PubMed: 9398832]

71. Cowley AW Jr, Nadeau JH, Baccarelli A, Berecek K, Fornage M, Gibbons GH, Harrison DG, Liang M, Nathanielsz PW, O’Connor DT, Ordovas J, Peng W, Soares MB, Szyf M, Tolunay HE, Wood KC, Zhao K, Galis ZS. Report of the National Heart, Lung, and Blood Institute Working Group on epigenetics and hypertension. Hypertension. 2012; 59(5):899-905. [PubMed: 22431584]

72. Reik W, Dean W, Walter J. Epigenetic reprogramming in mammalian development. Science. 2001; 293(5532):1089-93. [PubMed: 11498579]

73. Guibert S, Forné T, Weber M. Global profiling of DNA methylation erasure in mouse primordial germ cells. Genome Res. 2012; 22(4):633-41. [PubMed: 22357612]

74. Hackett JA, Sengupta R, Zylicz JJ, Murakami K, Lee C, Down TA, Surani MA. Germline DNA demethylation dynamics and imprint erasure through 5-hydroxymethylcytosine. Science. 2013; 339(6118):448-52. [PubMed: 23223451]

75. Smith ZD, Chan MM, Mikkelsen TS, Gu H, Gnirke A, Regev A, Meissner A. A unique regulatory phase of DNA methylation in the early mammalian embryo. Nature. 2012; 484(7394):339-44. [PubMed: 22456710]

76. Carone BR, Fauquier L, Habib N, Shea JM, Hart CE, Li R, Bock C, Li C, Gu H, Zamore PD, Meissner A, Weng Z, Hofmann HA, Friedman N, Rando OJ. Paternally induced transgenerational environmental reprogramming of metabolic gene expression in mammals. Cell. 2010; 143(7): 1084-96. [PubMed: 21183072]

77. Rassoulzadegan M, Grandjean V, Gounon P, Vincent S, Gillot I, Cuzin F. RNA-mediated nonmendelian inheritance of an epigenetic change in the mouse. Nature. 2006; 441:469-474.

[PubMed: 16724059] 


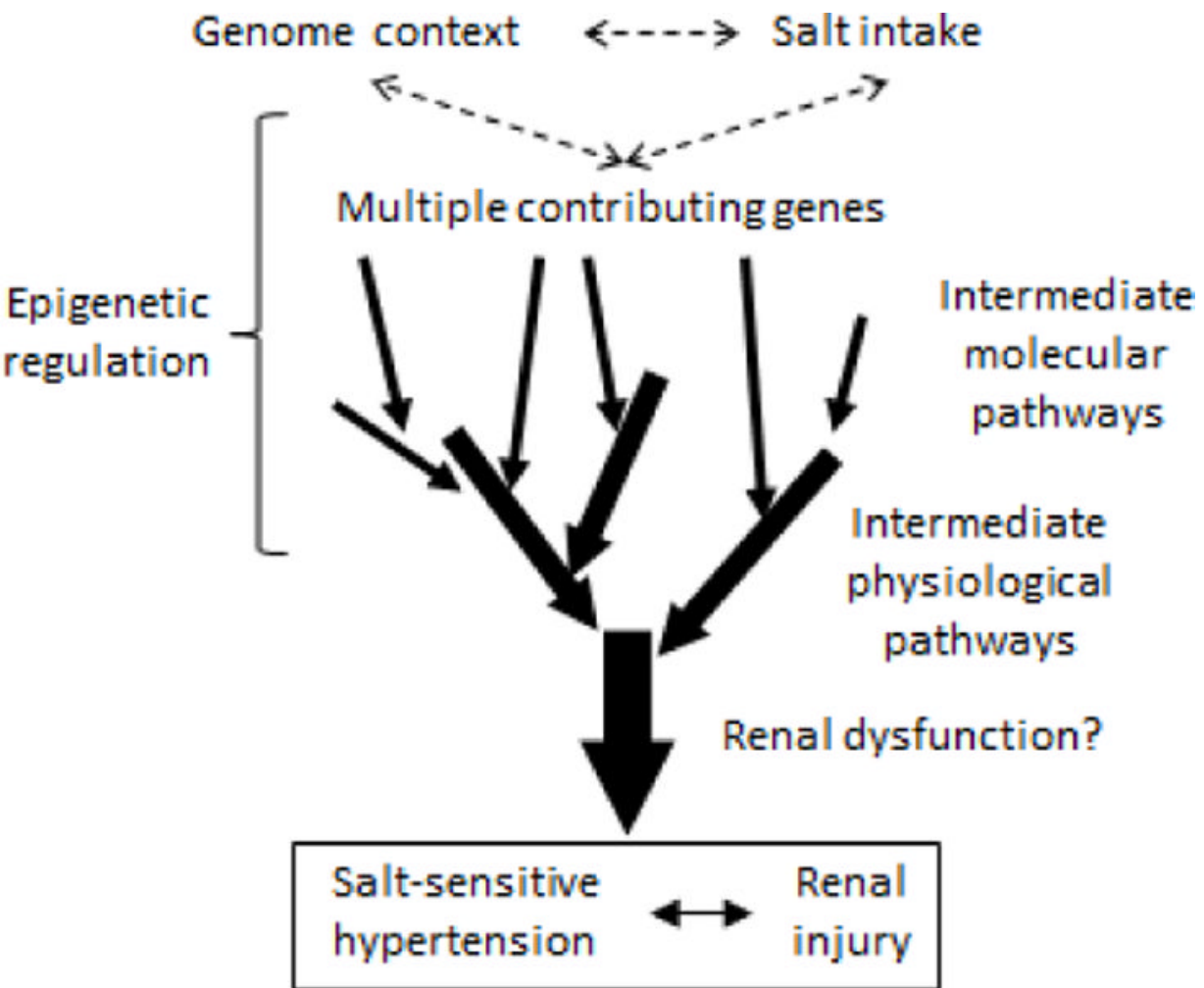

Figure 1. A tree-like paradigm for understanding the gene and pathway network underlying the development of salt-sensitive hypertension 


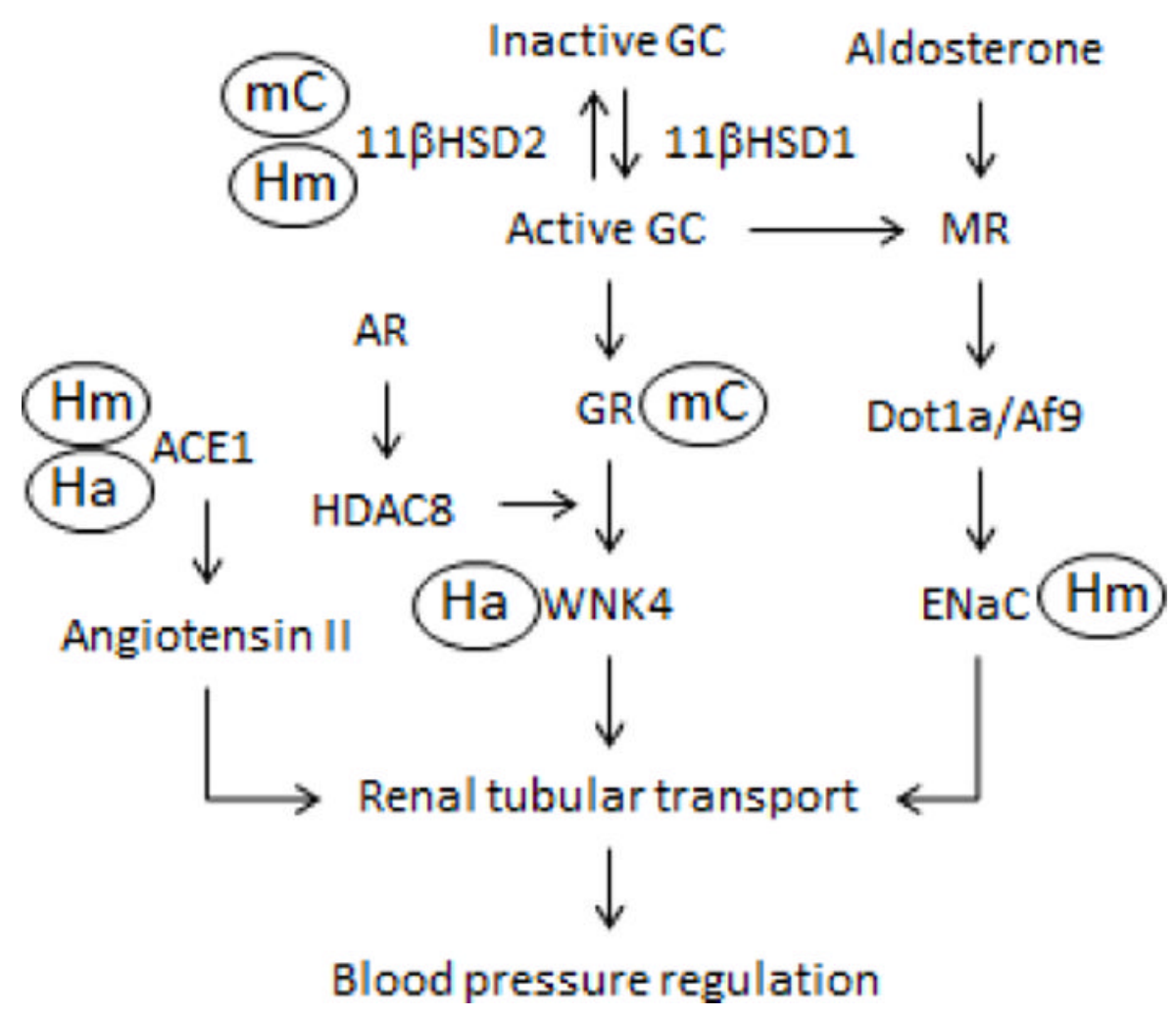

Figure 2. Several genes expressed in the kidney exhibit changes in epigenetic modifications that correlate with hypertension mC, DNA methylation; Hm, histone methylation; Ha, histone acetylation; ACE1, angiotensin converting enzyme 1; GC, glucocorticoids; HSD, hydroxysteroid dehydrogenase; GR, glucocorticoid receptor; AR, adrenergic receptor; HDAC, histone deacetylase; MR, mineralocorticoid receptor; $\mathrm{ENaC}$, epithelial sodium channel. 


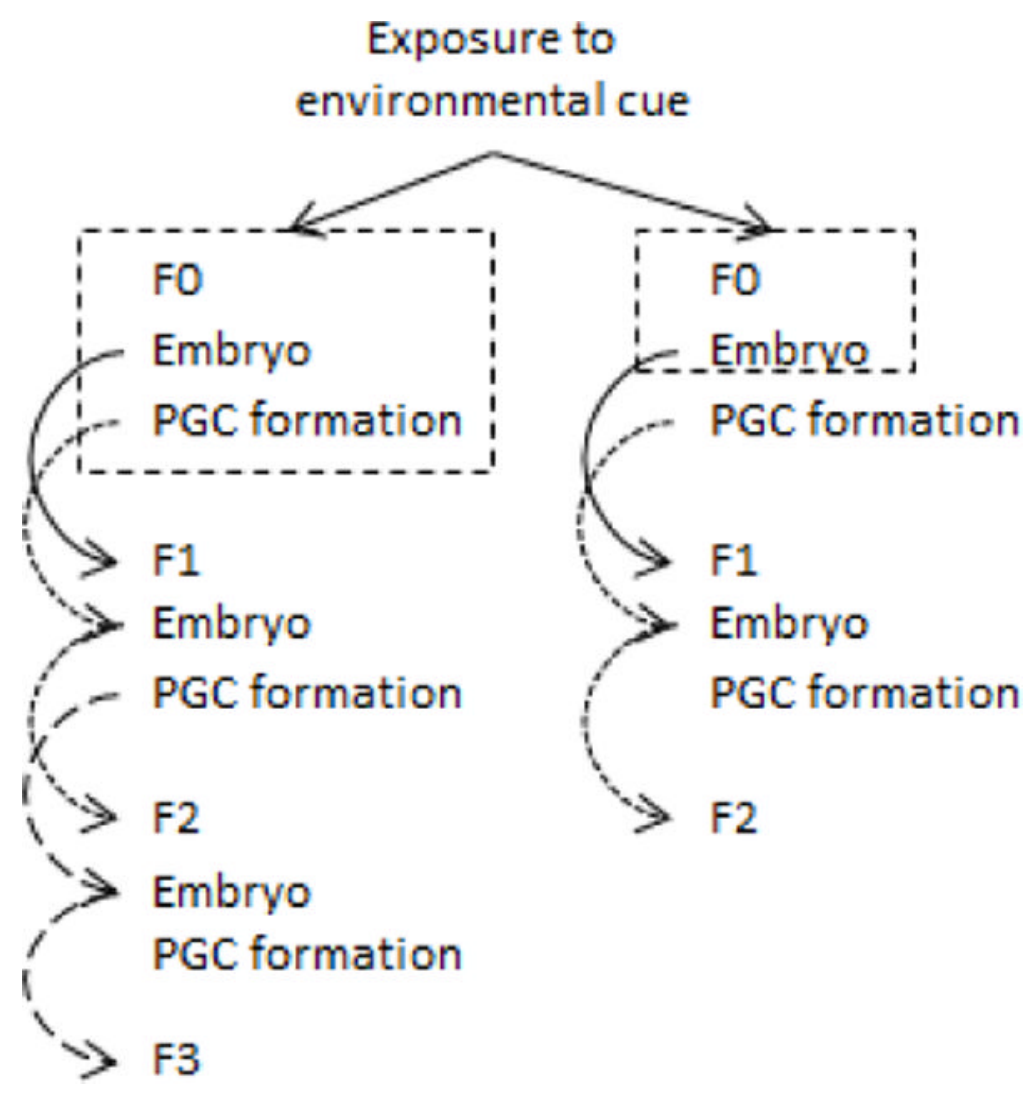

Figure 3. Transgenerational inheritance of epigenetic traits

(Left) Exposure to environmental cues occurs during pregnancy in F0. PGCs that give rise to F2 are exposed. (Right) Exposure occurs in F0 prior to pregnancy. Zygotes in F0 forming the embryo that develops to become F1 are exposed in this scenario. But PGCs that give rise to F2 are not exposed. PGC, primordial germ cell. 
Table 1

Examples of methods for genome-wide analysis of epigenetic marks

See the text for further detail and references.

\begin{tabular}{|l|l|}
\hline Epigenetic mark or mediator & Genome-wide analysis method (examples) \\
\hline DNA methylation & $\begin{array}{l}\text { Affinity purification and sequencing } \\
\text { Endonuclease digestion and bisulfite sequencing }\end{array}$ \\
\hline Histone modification & $\begin{array}{l}\text { Chromatin immunoprecipitation and sequencing } \\
\text { PTM-sensitive proteomics }\end{array}$ \\
\hline Non-coding RNA & RNA-seq \\
\hline
\end{tabular}

